
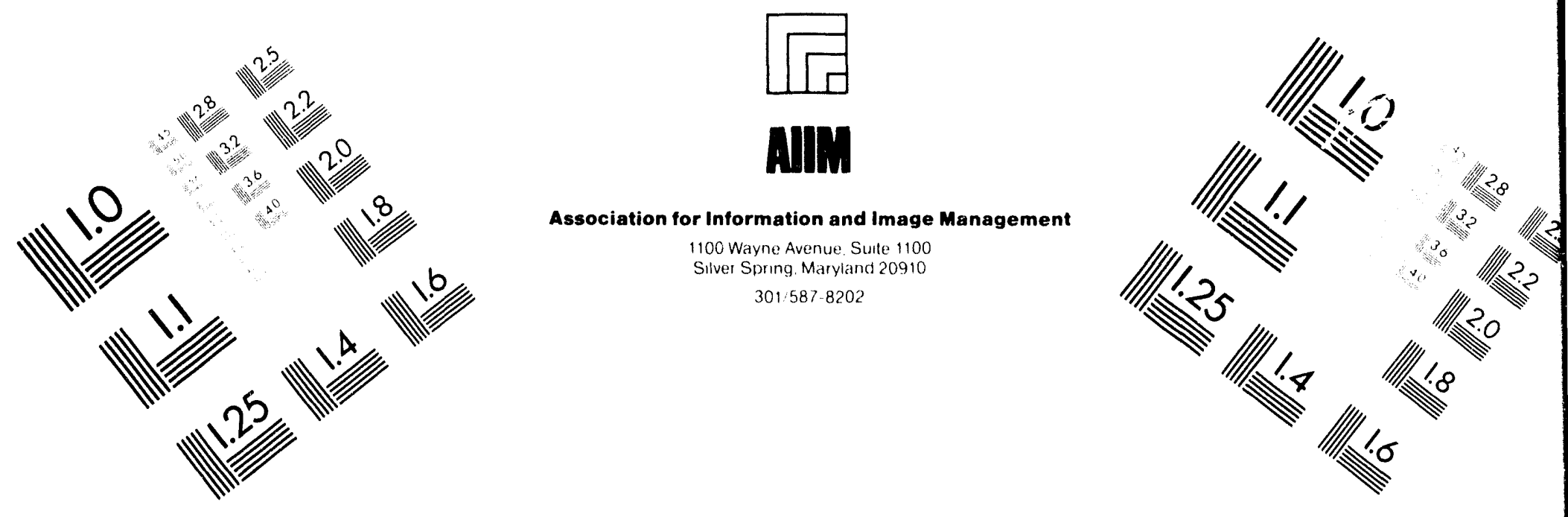

\title{
Centimeter
}

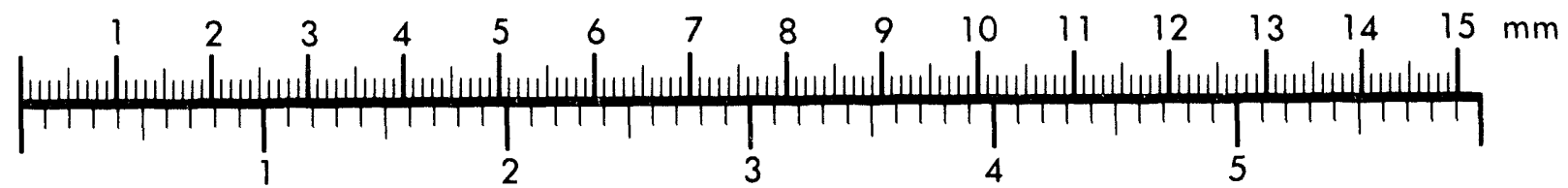

Inches
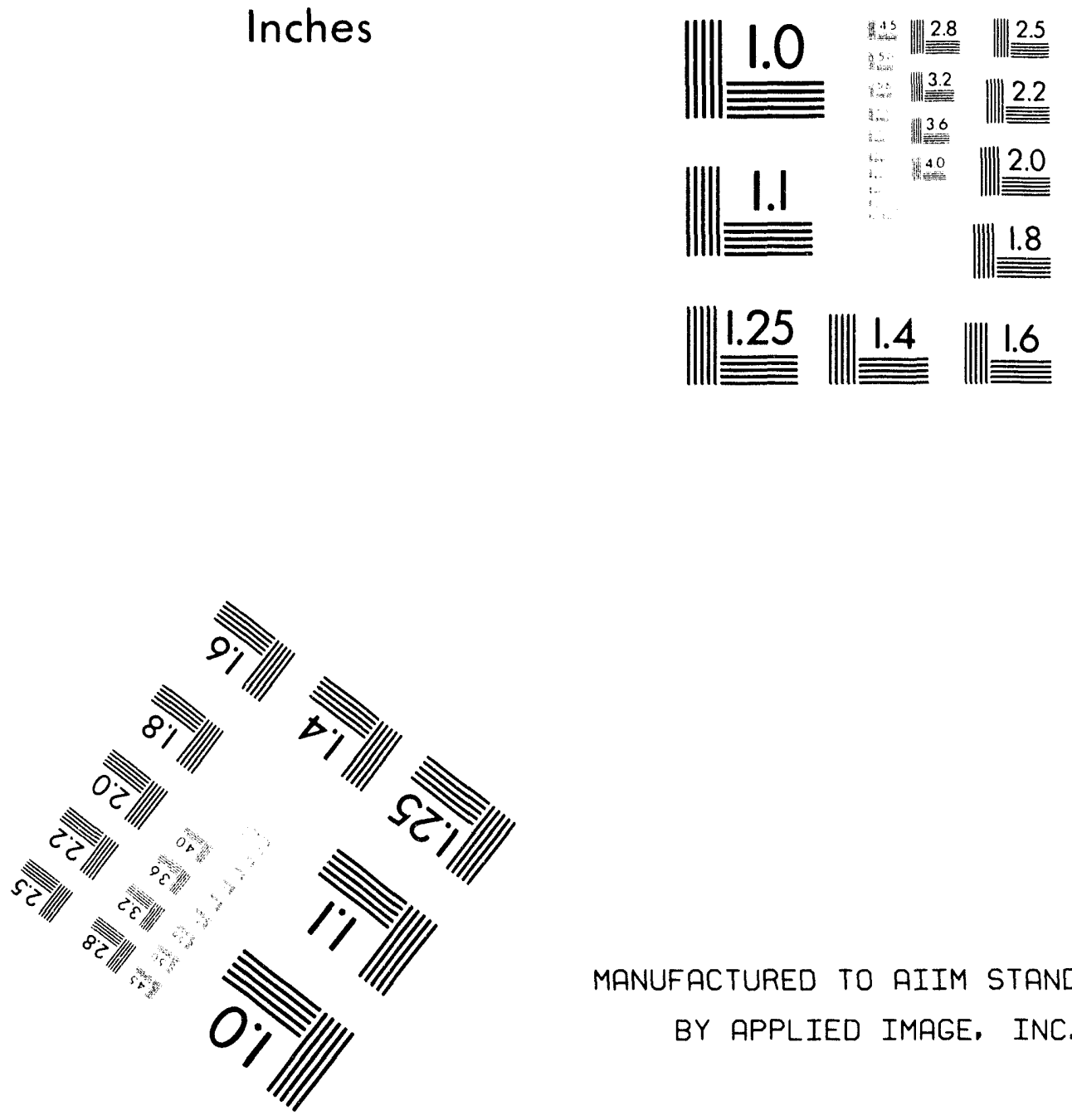

MANUFACTURED TO AIIM STANDARDS

BY APPLIED IMAGE, INC.

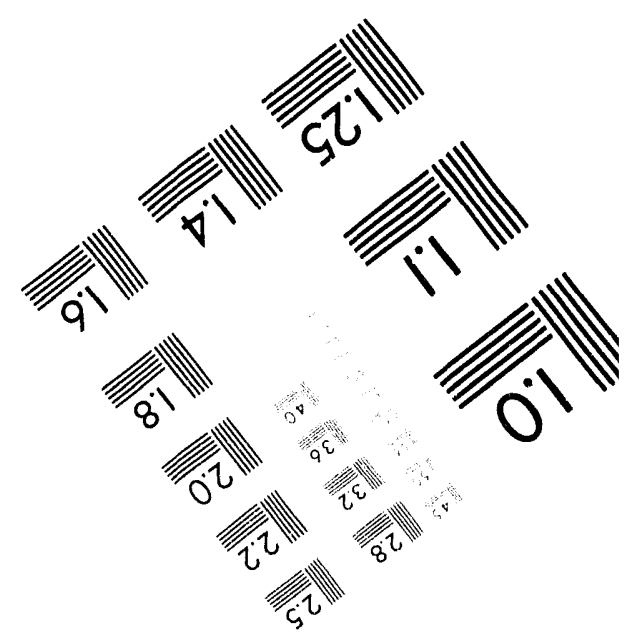



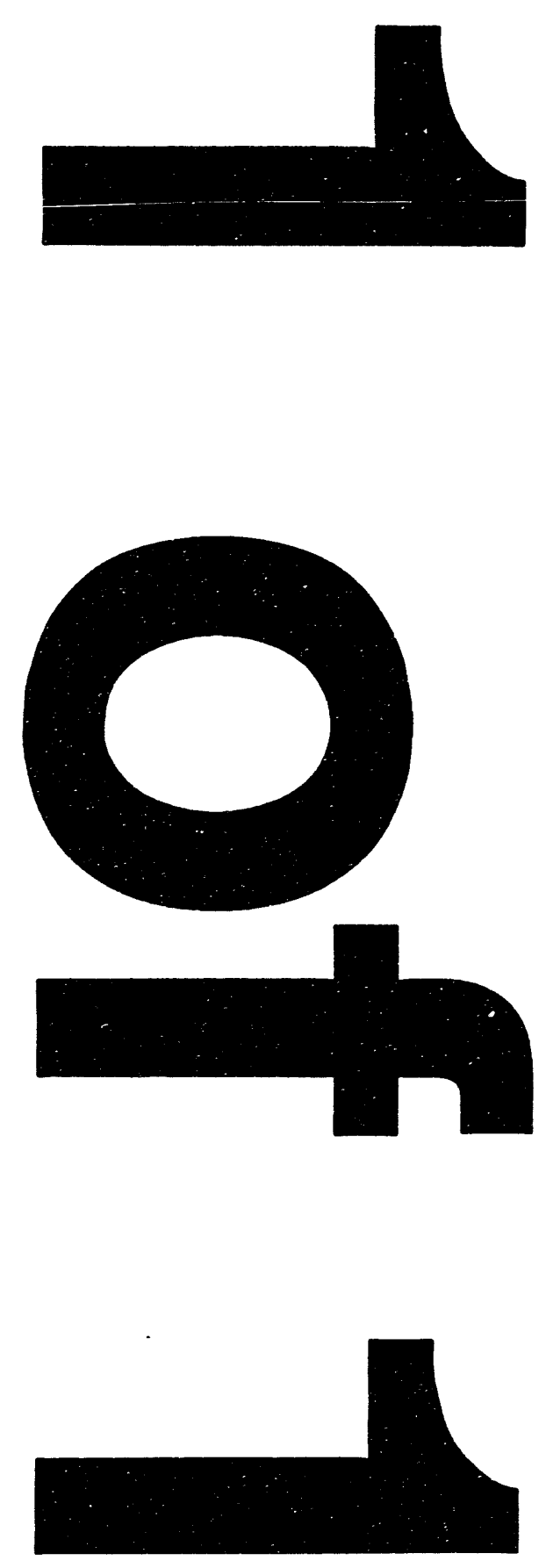


\section{Electric Vehicle Dynamic-Stress-Test Cycling Performance of Lithium-Ion Cells}

\section{Steven T. Mayer}

May 1994

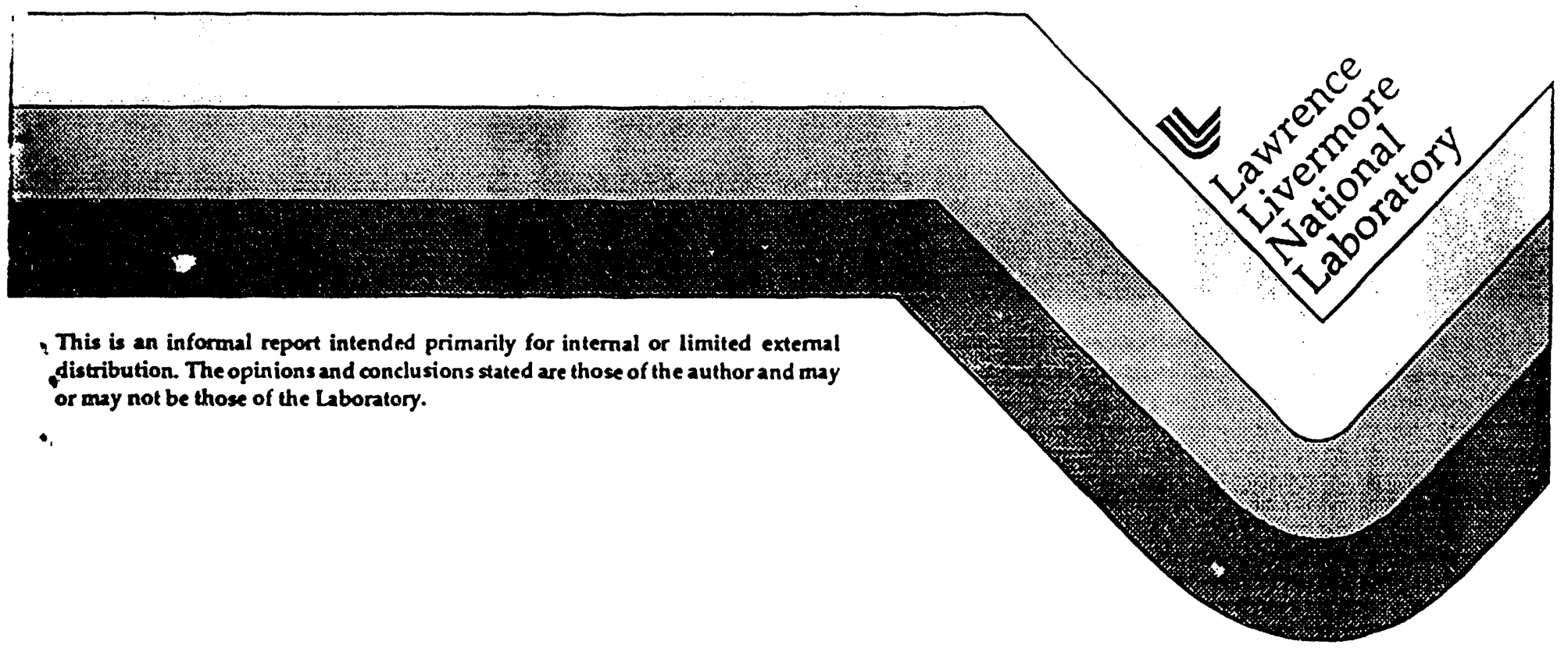




\section{DISCLAIMER}

This document was prepared as an account of work sponsored by an agency of the United States Government. Neither the United States Government nor the University of California nor any of their employees, makes any warranty, express or implied, or assumes any legal liability or responsibility for the accuracy, completeness, or usefulness of any information, apparatus, product, or process disclosed, or represents that its use would not infringe privately owned rights. Reference herein to any specific commercial products, process, or service by trade name, trademark, manufacturer, or otherwise, does not necessarily constitute or imply its endorsement, recommendation, or favoring by the United States Government or the University of California. The views and opinions of authors expressed herein do not necessarily state or reflect those of the United States Government or the University of California, and shall not be used for advertising or product endorsement purposes.

This report has been reproduced directly from the best available copy.

Available to DOE and DOE contractors from the Ofice of Scientific and Technical Information

$$
\text { P.O. Box 62, Oak Ridge, TN } 37831
$$

Prices available from (615) 576.8401, FTS 626-8401

Available to the public from the National Technical Information Service

US. Department of Commerce 5285 Port Royal Rd. Springfield, VA 22161 


\title{
Electric Vehicle Dynamic-Stress-Test Cycling Performance Of Lithium-Ion Cells
}

\author{
Steven T. Mayer \\ Chemical and Materials Science Division \\ Lawrence Livermore National Laboratory \\ Livermore, CA 94551
}

\begin{abstract}
Dynamic Stress tests (DST) of small lithium-ion cells have demonstrated that the systems delivers high energy ( $65 \mathrm{Wh} / \mathrm{kg}, 4.3$ hours runtime) with reasonable cycle-life (375-480 cycles) under the full USABC mid-term dynamic-stress-test conditions (150 W/kg). At lower DoD substantially higher cycle life was observed ( 2800 cycles at $44 \%$ DoD, 1.9 hours runtime). Both the DoD and charging voltage $V_{C}\left(4.1 \mathrm{~V}<V_{C}<4.2 \mathrm{~V}\right)$ affect the delivered energy and cell life in an interacting manner. At high DoD $(>80 \%)$, a lower $V_{C}$ is prefered because it maximize cycle life with a small penalty in energy. At intermediate DoD $(40-80 \%)$ a higher $V_{C}$ is preferred. Long-term tests are needed to determine the DST cycle life at very low DoD $(<40 \%)$. The high power pulse of the DST test limits the delivered cell energy and life. If a high energy density load leveling technology is developed (e.g. flywheels or double layer capacitors) the delivered energy and cycle life could be substantially increased.
\end{abstract}




\section{Introduction}

Since the introduction of lithium-ion batteries in 1991 by Sony Corporation, intense international interest has been paid to this and similar high-energy-density lithium intercalation systems. With the recent announcements of the intent of many other electronic and battery companies to manufacture lithium-ion batteries, the list of commsiciai suppliers is expected to grow rapidly in the near future. Investigation into the possible application of this technology to electric vehicles is of interest because of its relatively high energy, safety, and superior cycle life characteristics (compared to other presently available technologies).

The cell components are environmentally benign, consisting of carbon (the anode intercalation host), lithium cobalt oxide (the cathode intercalation host), propylene carbonate, diethylene carbonate, lithium hexaflourophosphate (these three making up the electrolyte) and two nonprecious metals, aluminum and copper (as anode and cathode current collectors, respectively). Only the toxicity of the salt (and its thermal stability) is a potential health issue. Tests have shown the cells to be consumer-safe under a variety of conditions. Work at LLNL has shown that several other more stable salt can be used instead which yields similar performance.

The economics of electric vehicles require that battery cost must be several orders of magnitude lower than those that are acceptable in the electronics industry. For example, the cost of small lithium-ion cells is approximately $\$ 25 \mathrm{Wh}$ (retail) in the 4th quarter of 1993. While this cost is expected to fall to less than $\$ 5 \mathrm{Wh}$ within 5 years, it does not come close to the $\$ 0.05$ to $0.2 \mathrm{Wh}$ required for an electric vehicle battery. A However, this comparison is probably misleading? For large battery systems under the forces of very large volumes and revenues, manufacturing technology and raw material cost become economic drivers. With this prospective, only the price of lithium cobalt oxide appears to be a potential problems source. This fact has spurred interest in several alternative cathode formulations (e.g. $\mathrm{LiNiO}_{2}$ and $\mathrm{LiMn}_{2} \mathrm{O}_{4}$ ).

Previously, cycle-life testing of Sony model 20500 lithium-ion cells were performed under various depth-of-discharge (DoD) at constant current conditions. The study showed that the cells had very good high rate capability, and that at moderate discharge rates and low DoD's, the cells exhibits extremely high cycling capability (C/3 discharge, $30 \% \mathrm{DOD},>40,000$ cycles)[1]. It is the purpose of this project to investigate the performance of the same type of small lithium-ion cells (model 20500) under

A The USABC mid-term goals (late 1990's) is a specific power of $150 \mathrm{~W} / \mathrm{kg}$, a specific energy of $80-100$ $W \cdot h r / k g$, a life of 5 years, and a cost of under $\$ 0.15 / W \cdot h r$. [2]. 
standardized cycle-life test conditions specifically developed for electric vehicle application. The Dynamic-Stress-Test (DST), recently developed by the United Stated Advanced Battery Consortium (USABC) was used at various "discharge cycle"B end conditions to determine the effects of DoD and charging conditions on the life performance of lithium-ion cells. Impedance measurements were taken at the beginning of life and at various points in the test as a means of further accessing the condition of the cell during the cycling process.

It is not the intent of to imply this study to suggest that tests of small spirially wound cells should be directly applied an indication of cycle life or performance for a battery which will ultimately be 4 orders of magnitude greater in mass and volume (i.e. an electric vehicle battery). Such a battery will involve the series connection of about 100 prismatic cells each having nearly 80 times the capacity of the cells studied here. Cell balancing and charging controls will be an important issue. Therefore, the results of this study are useful only in demonstrating the potential use of this (and to a lesser extent other) lithium-ion technologies in electric vehicles. To fully understand the performance of full-scale cells in this application, actual prototypes of larger cells will need to be manufacture. Development of large prismatic cells should benefit from the testing of smaller cell and from the application of computer modeling during the design and fabrication phases.

\section{Experimental}

A 64 channel Maccor battery tester was used to measure the initial capacities and to run the DST tests on all cells. This tester allows multiple independently programmable channels to be run simultaneously. It was programmed to continuously cycle the lithium-ion cells between preset end-of-discharge and charging conditions. Since the DST test requires a series of constant power step (see below for details), a four wire arrangement was used (two current carrying wires and two sense lines). Impedance tests were performed using an AC-impedance upgraded EG\&G PAR model 273 potentiostat and a lock-in amplifief (model 5210) connected to a PC computer. EG\&G impedance software M398 was used to collect the data.

\section{Initial Cell Analysis}

Details of the model 20500 cell design were described in reference 1. The two cells which make up the battery were removed from their plastic housing and cut from their electrical connections prior to testing. All cells were found to be in a partially

\footnotetext{
B The term "discharge cycle" is used in this report to indicate a cycle which is an combination of many DST cycle waveforms. The term "DST cycle" is used to indicate an individual DST waveform which makes up the larger discharge cycle.
} 
charged state when received (from about 3.6 to $3.8 \mathrm{~V}$ ). The identification markings plus a letter designation will be used as a cell designation. This identification marking appears to indicate the manufacture date (e.g. 261111 may translate to the $26^{\text {th }}$ of November, 1991, with the last number being the lot number). Ten cells were initially charged at $450 \mathrm{~mA}$ to $4.1 \mathrm{~V}$, and then potentiostatically held at $4.1 \mathrm{~V}$ for 3 hours, followed by a discharged at $180 \mathrm{~mA}(\mathrm{C} / 5)$. Capacity and energy were recorded during the discharge. The process was repeated again, except the second time a charging voltage of $4.2 \mathrm{~V}$ was used. Finally, the cells were recharged to $3.5 \mathrm{~V}$ (held at $3.5 \mathrm{~V}$ for $3 \mathrm{hrs}$ ), and an initial $A C$ impedance measurement $(5 \mathrm{mHz}$ to $10 \mathrm{kHz})$ was taken. Table 1 gives the initial capacity, energy, and $10 \mathrm{kHz}$ resistance of all cells used in this study. With the exception of the last entry in the table, the cell capacities, energies and resistance values are all similar. The apparent density of the cells is about $2.45 \mathrm{~g} / \mathrm{cc}$, so the energy density ranges from 200 to $240 \mathrm{Wh} / \mathrm{l}$ (depending on charging voltage). The cell with the most recent manufacture date has the highest energies. Early in the study, 3 cells were accidentally destroyed as a results of a power failure and a tester failure. After correction of the problem, these cells were replace with new cells (denoted by ${ }^{*}$ in Table 1). These cycling calendar life of these cells was slightly less the others.

The AC impedance response of lithium-ion cells was found to be a strong function of potential. Figure 1 is a Nyquist plot of the 20500 cells at several different states of charge (reflected in the unpolarized cell voltage). There is one large semicircle loop which may overlapp with another smaller loop at high frequencies. The radius of the larger semi-circle loop increases almost 100 fold from about $0.05 \Omega$ at full

Table 1

Initial Performance of Sony Lithium Cells

\begin{tabular}{|c|c|c|c|c|c|}
$\begin{array}{c}\text { Cell } \\
\text { Identification } \\
\text { Markings }\end{array}$ & $\begin{array}{c}4.1 \mathrm{~V} \text { Capacity } \\
\text { (Ah) }\end{array}$ & $\begin{array}{c}4.1 \mathrm{~V} \text { Specific } \\
\text { Energy } \\
\text { (Whkg) }\end{array}$ & $\begin{array}{c}4.2 \mathrm{~V} \\
\text { Capacity } \\
\text { (Ah) }\end{array}$ & $\begin{array}{c}4.2 \mathrm{~V} \text { Specific } \\
\text { Energy } \\
\text { (Wh/kg) }\end{array}$ & $\begin{array}{c}10 \mathrm{kHz} \text { Cell } \\
\text { Resistance } \\
\text { (m) }\end{array}$ \\
\hline $26111-1(\mathrm{a})$ & 0.947 & 82.3 & 1.06 & 93.7 & 51.9 \\
\hline $03101-3(\mathrm{~b})$ & 0.912 & 80.0 & 1.03 & 90.8 & 50.4 \\
\hline $26111-1(\mathrm{c})$ & 0.948 & 83.0 & 1.06 & 94.2 & 51.5 \\
\hline $26111-1(\mathrm{~d})$ & 0.929 & 81.6 & 1.04 & 92.8 & 52.1 \\
\hline $26111-1(\mathrm{e})$ & 0.943 & 82.5 & 1.06 & 94.2 & 53.4 \\
\hline $26111-1\left(\mathrm{f}^{*}\right.$ & 0.918 & 80.0 & 1.03 & 90.7 & 60.4 \\
\hline $24031-2(\mathrm{~b})$ & 0.943 & 82.7 & 1.05 & 93.8 & 53.3 \\
\hline $03101-3(\mathrm{a})$ & 0.942 & 82.6 & 1.06 & 93.9 & 52.7 \\
\hline $03101-3(\mathrm{c})$ & 0.910 & 80.0 & 1.02 & 90.5 & 51.2 \\
\hline $13032-2(\mathrm{a})$ & 0.982 & 86.3 & 1.10 & 97.9 & 50.8 \\
\hline
\end{tabular}

"replacement cell. See text. 


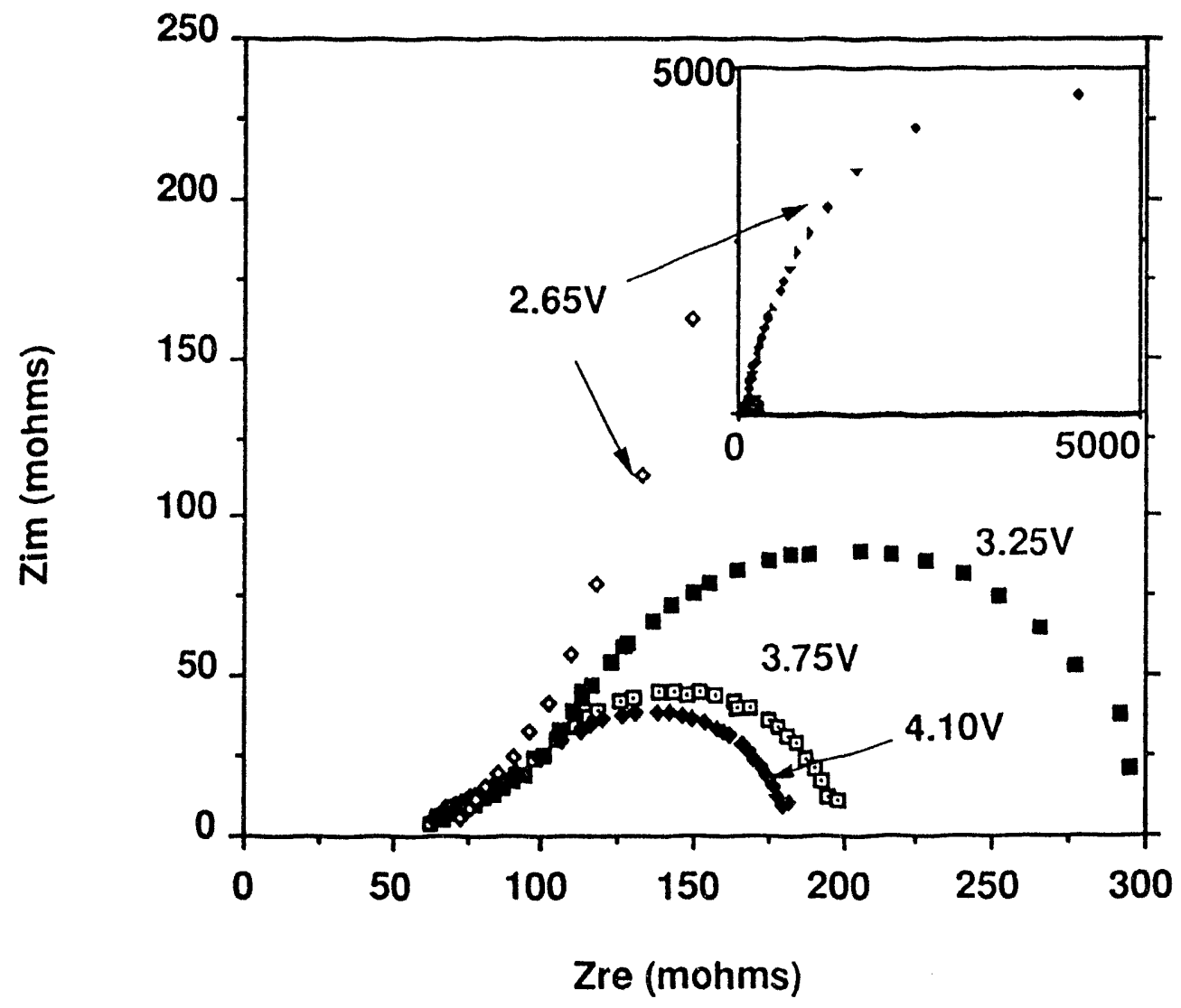

Figure 1

Initial AC Impedance at Various DOD's

charge (4.1V) to about $5 \Omega$ near full discharge (2.65V) on the real axis and from about $0.035 \Omega$ to $5 \Omega$ on the imaginary axis. For discharges to a voltage of about $3.5 \mathrm{~V}$ (or up to approximately $60 \%$ discharge), the impedance changes are relatively small, but near the fully discharged state the rate of increase becomes large. Because of the sensitivity of the AC impedance response to cell voltage, all impedance tests used to monitor cell life were performed at a standard $3.5+/-0.025 \mathrm{~V}$. The cells were maintained at $3.5 \mathrm{~V}$ for 3 hours prior to running an impedance test.

\section{4) The Dynamic Stress Test (DST)}

Figure 2 shows the "full-scale" mid-term USABC DST waveform. This cycling waveform was used for all the cells in this study. This changes was made because it simplified the data processing using the existing Maccor battery tester software. The peak power pulse was moved from the middle of the cycle to the end of the cycle. The full mid-term DST waveform calls for an eight-second maximum discharge power pulse of $150 \mathrm{~W} / \mathrm{kg}$, and a maximum eight-second charge pulse of $75 \mathrm{~W} / \mathrm{kg}$. The averaged discharge power of the cycle (including charging contributions) is $15 \mathrm{~W} / \mathrm{kg}$. Since the DST cycle duration is 6 minutes, there are ten DST cycles per hour, and each DST 
cycle consumes $1.5 \mathrm{Wh} / \mathrm{kg}$. Tests were performed using repeated application of the DST waveform to a predetermined cutoff condition. The partial DoD tests

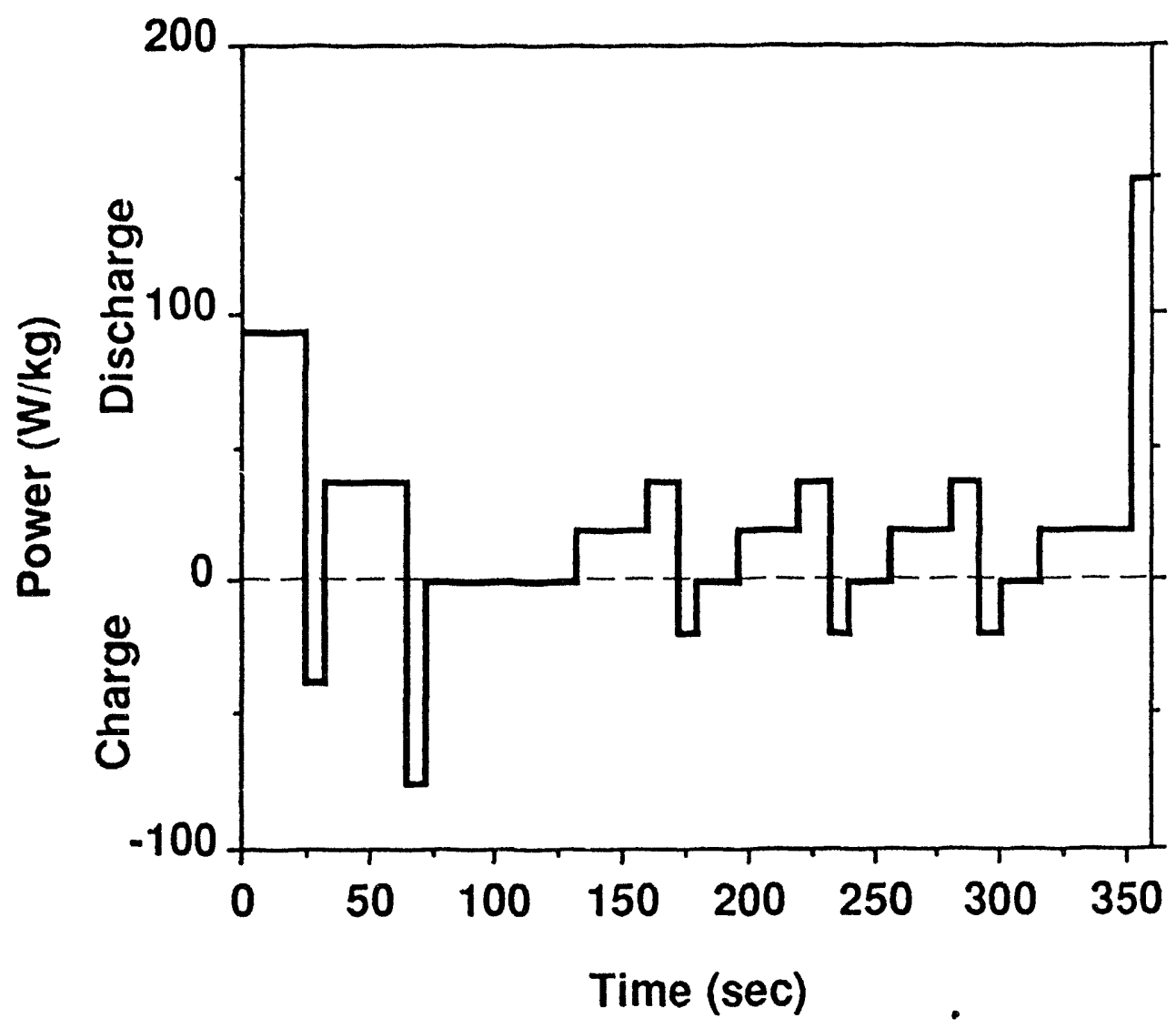

Figure 2

Dynamic Stress Test (DST) Waveform

were based on the percent of energy extracted from the cell relative to the cells initial energy ( $\mathrm{C} / 5$ rate) at the corresponding charge voltage used. It is very important to note that, in this study, DoD refers to energy and not capacity. Because the DST waveform is more stressful than a $\mathrm{C} / 5$ constant current discharge used by the manufacturer to determine nameplate capacities, less than $80 \%$ of the capacity shown in table 1 can be extracted from the cells under DST discharge. As an example, a $4.1 \mathrm{~V}$ charged, $30 \%$ DOD cell is cycled until approximately $0.30 \times 80 \mathrm{Wh} / \mathrm{kg}=24 \mathrm{Wh}$ of energy is extracted. This corresponds to 16 DST cycles, and $1.6 \mathrm{hrs}$ of runtime. Partial cycles were rounded to the nearest integral number of cycles. Two "100\%" DOD end conditions were also used in this study. The first requires recharge once the $2.5 \mathrm{~V}$ cutoff voltage is reached. Since the high-power DST step is the last step in the DST cycle, recharge occurs immediately after this conditions is met. The second end-point condition requires continue cycling with a minimum voltage controlled so that it does not surpass the cutoff voltage (2.5V) and until $2 / 3$ of the peak power can no longer be supplied (100 W/kg). This end-point specification is the full USABC DST end point condition. Basically, once the cell can no longer supply $150 \mathrm{~W} / \mathrm{kg}$ at $2.5 \mathrm{~V}$, the cell supplies as much power as it 
can while being potentiostatically heid at $2.5 \mathrm{~V}$. Once the average power for that DST step dips below $100 \mathrm{~W} / \mathrm{kg}$, the cell is recharged. Table 2 gives the various test conditions used for the cell studied.

Figure 3 shows the voltage versus time for the first discharge cycle of the full DST, $V_{C}=4.2 \mathrm{~V}$ charged cell (cell 24031-2 (b)). The rate at which the voltage decreases increases during the discharge cycle. This is largely due to the fact that during the discharge cycle the DST power-profile requirements remain constant while the cell voltage decreases resulting in larger current (and larger ohmic contributions) toward the end of the discharge cycle. The spikes above and below the average trend line correspond to the high-power charge and discharge components of the DST cycle. The difference between the voltage under peak stress and the average voltage increases from about $250 \mathrm{mV}$ at full charge to $450 \mathrm{mV}$ near the end of discharge.

Figure 4 is a plot of an expanded portion of the data of Figure 3, and more clearly indicates the effects the constant power steps have on the cell voltage. Both the voltage changes due to the ohmic and faradaic charging/discharge can be seen. The changes in voltage during the low -power steps lie within a $125 \mathrm{mV}$ range, but the voltage difference between the high-power discharge and charge steps are much greater, about $400 \mathrm{mV}$. As can be seen in figure 3, it is the high power pulse step which limits the usable energy to about $65 \mathrm{Wh} / \mathrm{kg}(4.3 \mathrm{hrs})$ under this test program. Load

Table 2

Cell Cycling Conditions

\begin{tabular}{|c|c|c|c|c|c|}
$\begin{array}{c}\text { Cell } \\
\text { Identification } \\
\text { Markings }\end{array}$ & $\begin{array}{c}\text { Approximate } \\
\text { Depth of } \\
\text { Discharge } \\
(\%)\end{array}$ & $\begin{array}{c}\text { Charging } \\
\text { Voltage } \\
\text { (Volts) }\end{array}$ & $\begin{array}{c}\text { Number of } \\
\text { DST cycles } \\
\text { (Runtime, hrs) }\end{array}$ & $\begin{array}{c}\text { Power End } \\
\text { Point Condition } \\
\text { (W/kg) }\end{array}$ & $\begin{array}{c}\text { Energy } \\
\text { Delivered } \\
\text { (Whr/kg) }\end{array}$ \\
\hline $26111-1(\mathrm{a})$ & 30 & 4.20 & $19(1.9)$ & None & 28.5 \\
\hline $03101-3(\mathrm{~b})^{*}$ & 30 & 4.10 & $16(1.6)$ & None & 24 \\
\hline $26111-1(\mathrm{c})$ & 100 & 4.15 & $42(4.2)$ & 100 & 63 \\
\hline $26111-1(\mathrm{~d})$ & 100 & 4.20 & $40(4.0)$ & 150 & 60 \\
\hline $261111-1(\mathrm{e})$ & 100 & 4.10 & $34(3.4)$ & 150 & 51 \\
\hline $261111-1()^{\circ}$ & 50 & 4.10 & $27(2.7)$ & None & 40.5 \\
\hline $24031-2(\mathrm{~b})$ & 100 & 4.20 & $43(4.3))$ & 100 & 64.5 \\
\hline $03101-3(\mathrm{a})$ & 50 & 4.20 & $31(3.1)$ & None & 46.5 \\
\hline $03101-3(\mathrm{c})^{\circ}$ & 100 & 4.10 & $40(4.0)$ & 100 & 60 \\
\hline $13032-2(\mathrm{a})$ & 50 & 4.15 & $31(3.1)$ & None & 46.5 \\
\hline
\end{tabular}

Replacement cells. See text.

${ }^{1}$ Corresponds only to the first discharge-cycle for $100 \%$ DOD cells.

${ }^{2}$ Corresponds only to first discharge-cycle energy delivered for $100 \%$ DOD cells 


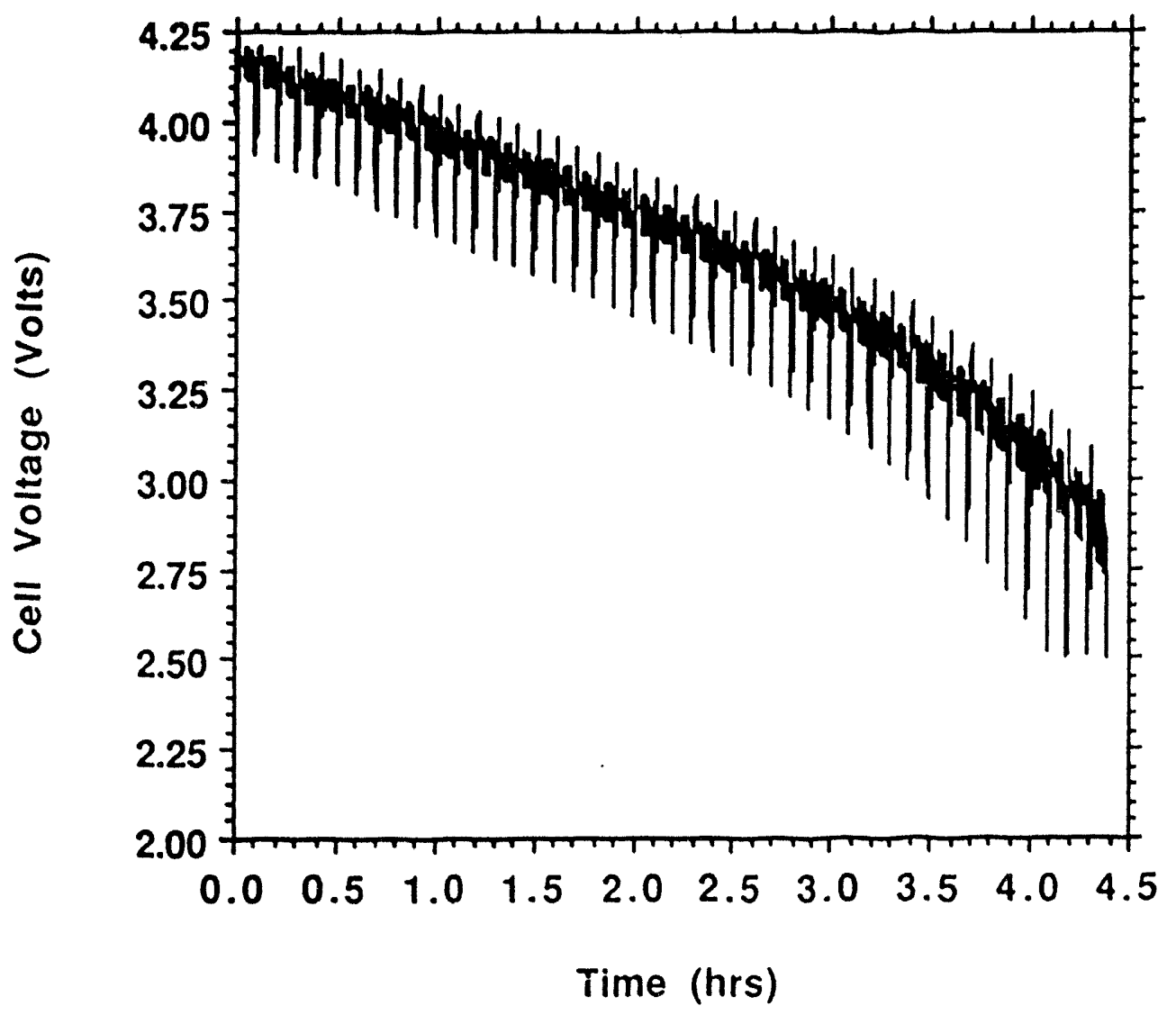

Figure 3

DST Discharge Voltage vs. Time

4.2V Charge, $2.5 \mathrm{~V} / 100 \mathrm{~W} / \mathrm{kg}$ Cutoff

leveling of the profile with an electrochemical capacitor should increase the "driving range" substantially.

\section{DST Cycle Life Tests Results}

The voltage progression during the DST discharges high-power discharge pulse is shown in Figure 5 for several different discharge cycles. The results are for the $V_{c}=4.2 \mathrm{~V}$ cell discharged to full DST $100 \mathrm{~W} / \mathrm{kg}$ end-point condition. The progression of curves deviate from each other most notably at the low voltage end of the curve. As the cell degrades, the effect is largely seen in higher cell polarization in the later half of the cells discharge. This decrease reflect a loss of capacity, and an increasing ohmic, charge transfer, and diffusion resistance. On the other hand, the first DST-cycle-voltage decreases much less with discharge cycle, reflecting changes only in the ohmic resistance of the cell. Cell runtime is reduced from 258 to 210 minutes after 265 cycles. 


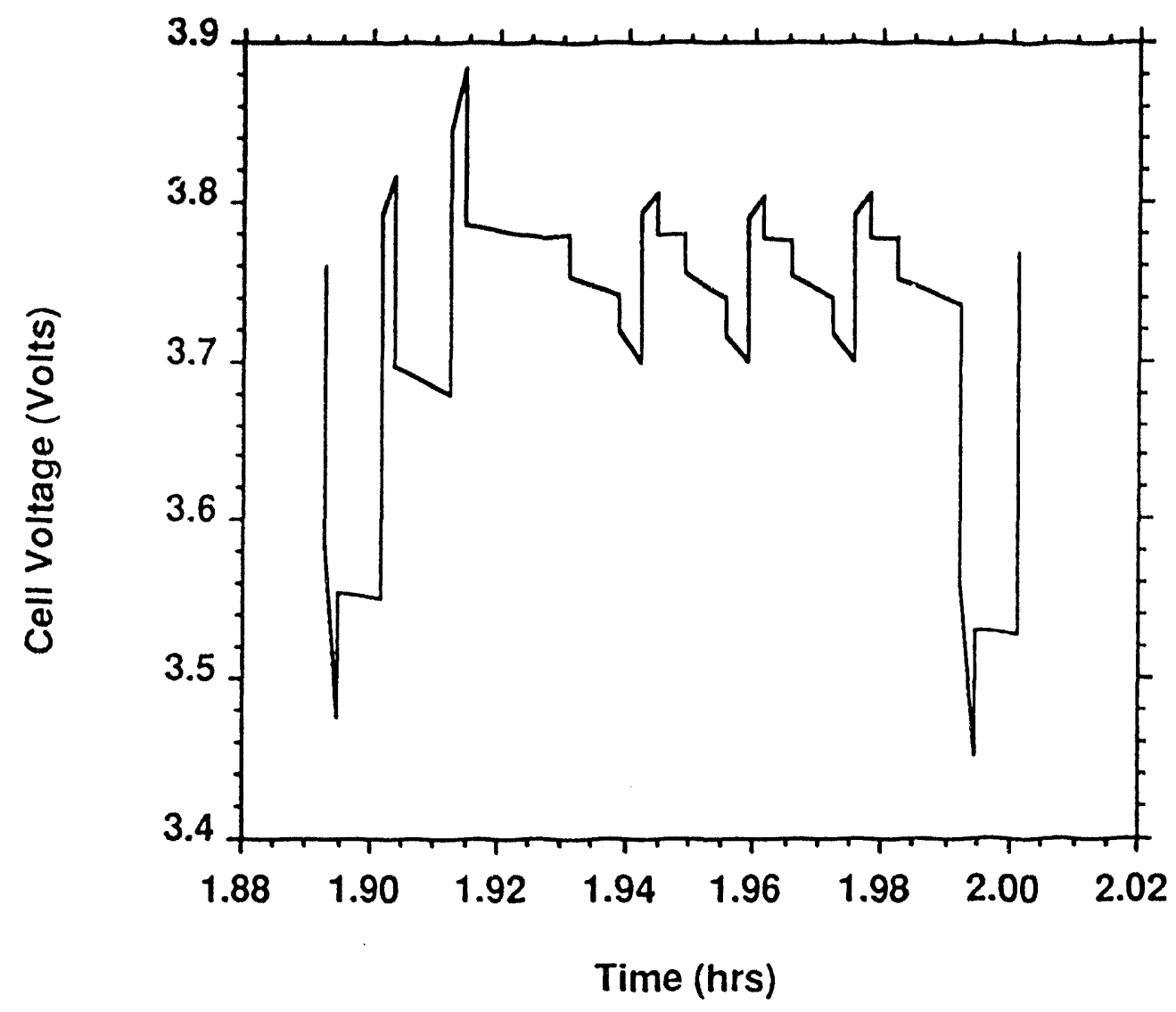

Figure 4- Single DST Cycle Voltage vs. Time

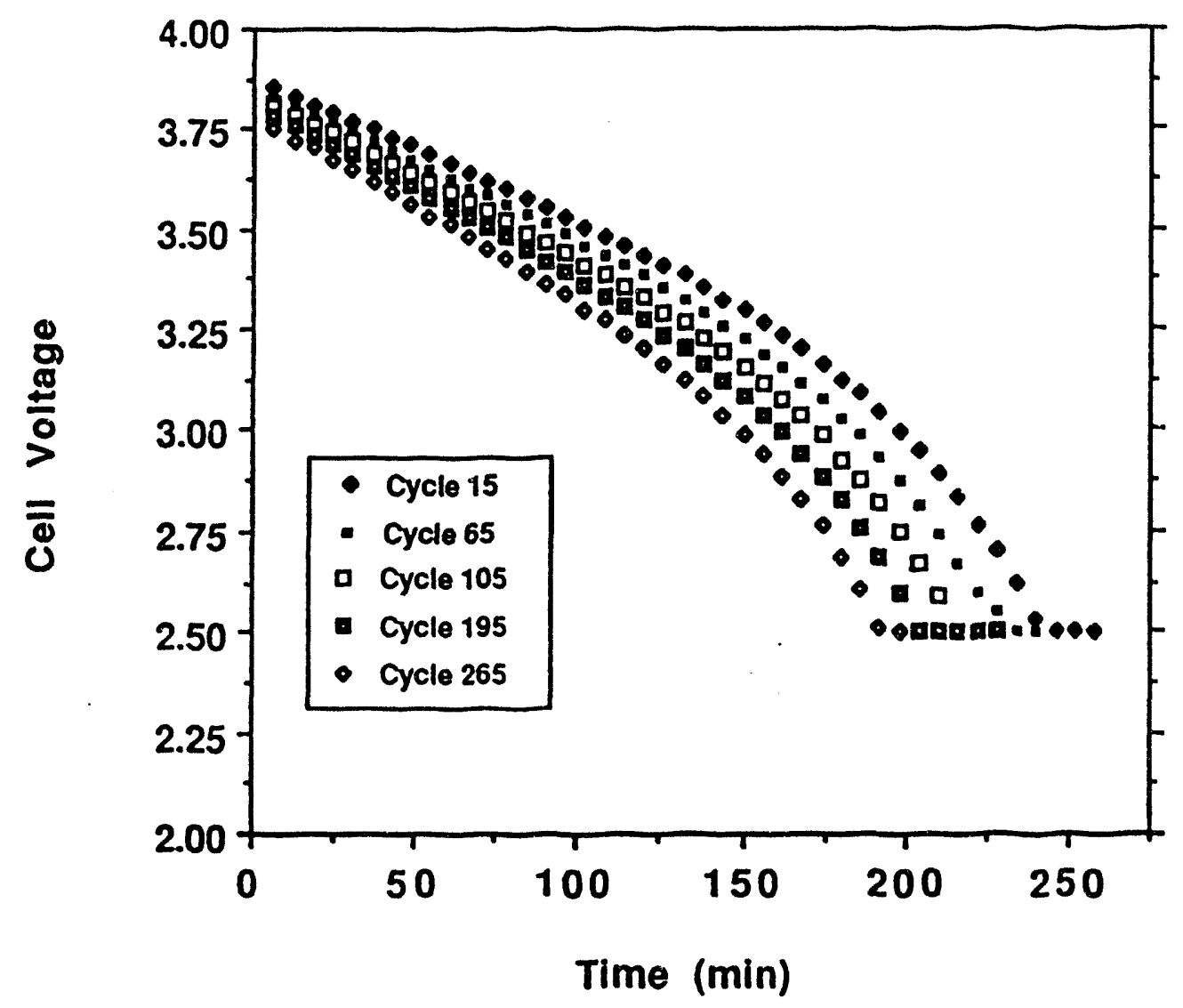

Figure 5- DST Peak Power Point Voltages

For a 4.2V Charge Cell 
Figure 6-8 show the DST cycle runtime for several different $100 \%-D o D$ cells. Cells that were charged at $V_{C}=4.1$ and $4.15 \mathrm{~V}$ initially show a relatively fast reduction in runtime with discharge cycle, but later decrease more slowly and at a linear rate. Although data points exist for every discharge cycle, only a few points are shown which (generally) correspond to points were AC impedance measurement were made. Also, since the result are integer values (no fractions of a DST cycle were possible) only longterm trends are significant. Lines are drawn which show the extrapolated point at which the runtime should decrease to $75 \%$ of the measured first cycle runtime. The $75 \%$ cutoff point is arbitrarily chosen to define the cycle life of the $100 \%$ DoD tests, and is plotted in Figure 9.

In general, the cycle life increases with decreasing charge cutoff voltage $V_{C}$ and higher cutoff-power (remember that higher cutoff-power cells actually recharges at a lower discharge energy and capacity than those with a lower cutoff-power because of the required deeper discharges). Depending on the charging and discharging conditions, cells cycled at $100 \%$ DOD under the DST waveform lose $25 \%$ of their initial capacity after 375 to 600 cycles.

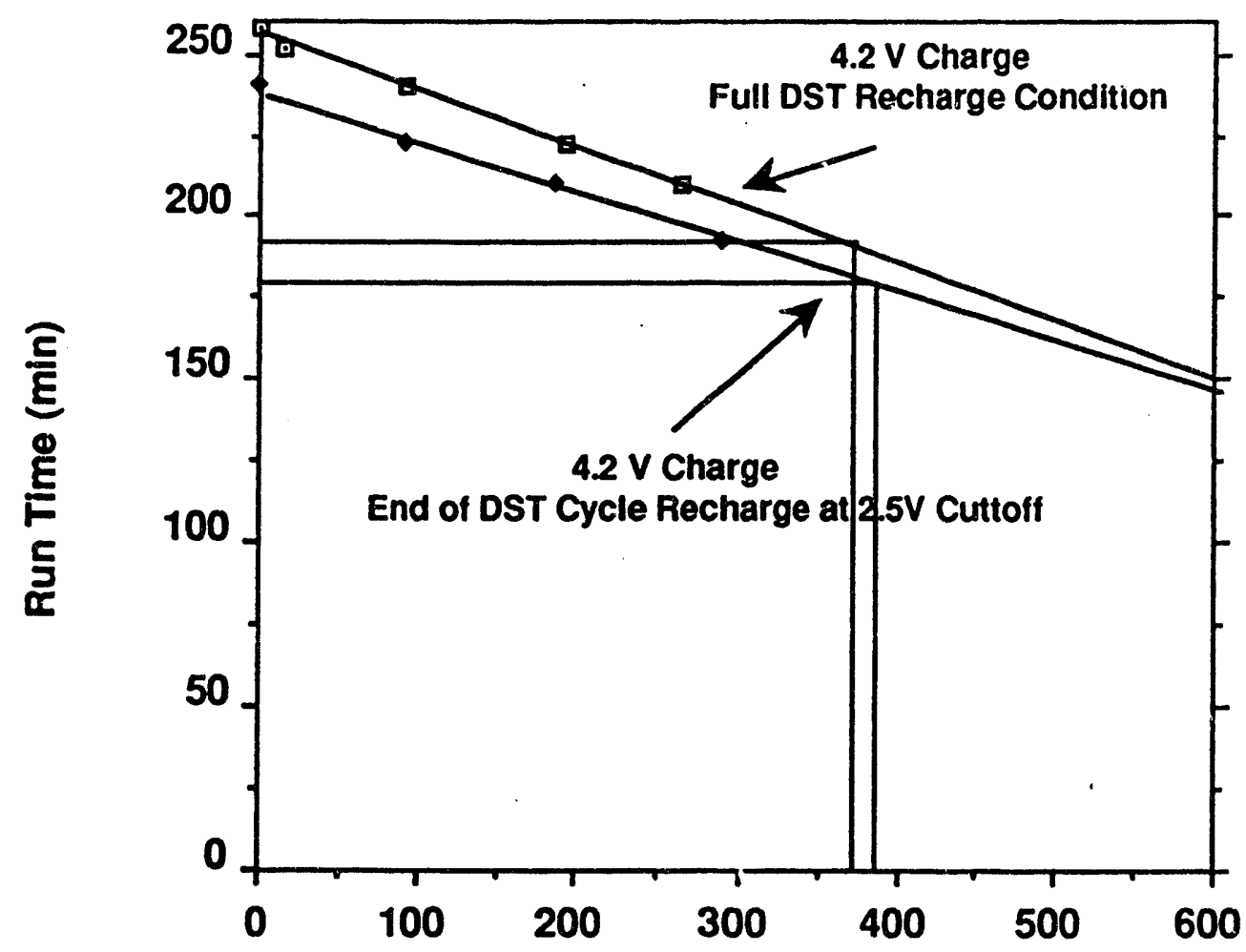

Discharge Cycle Number

Figure 6- 4.2V Charge Cell Runtimes 


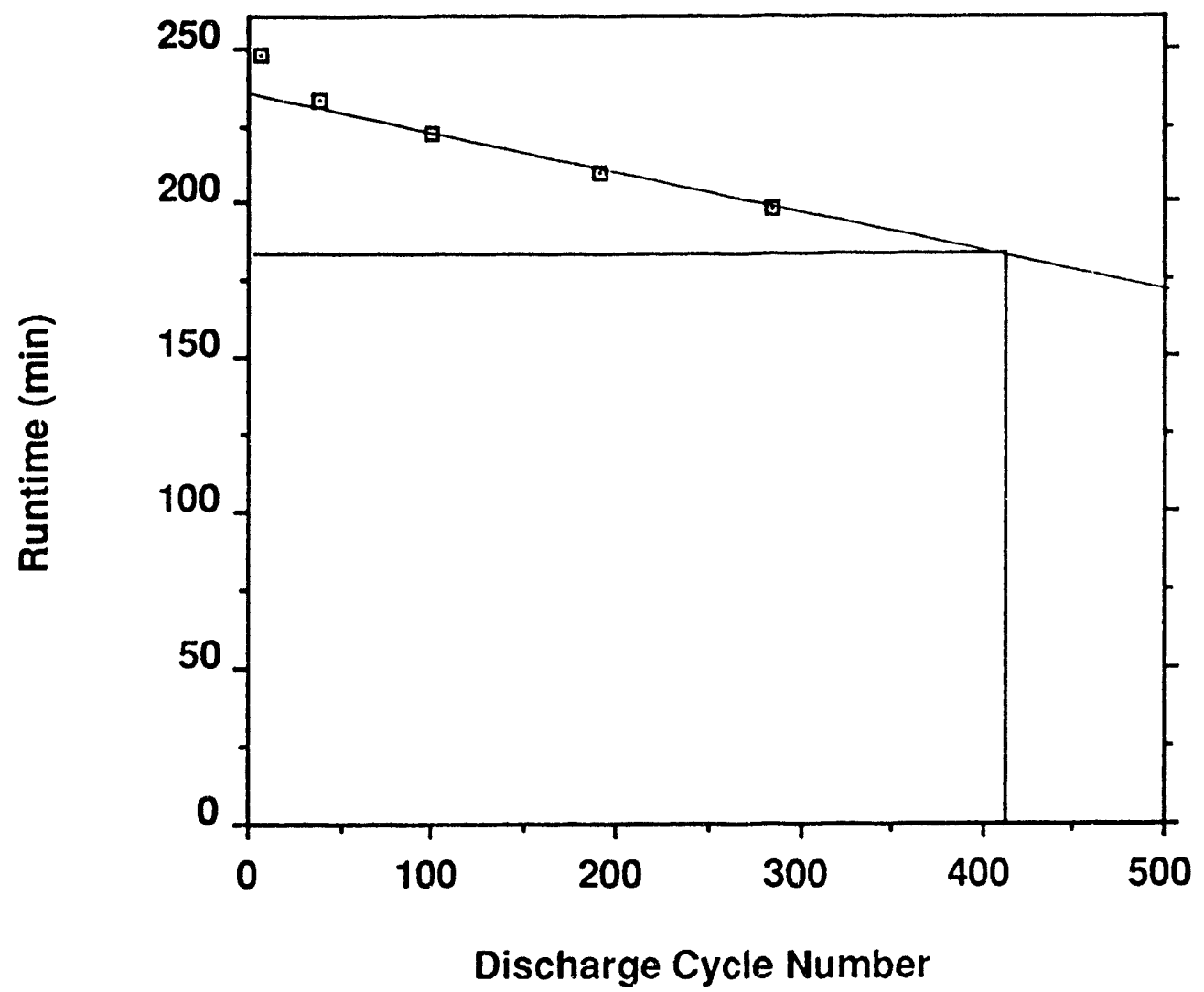

Figure 7- 4.15V Charge Cell Runtime,

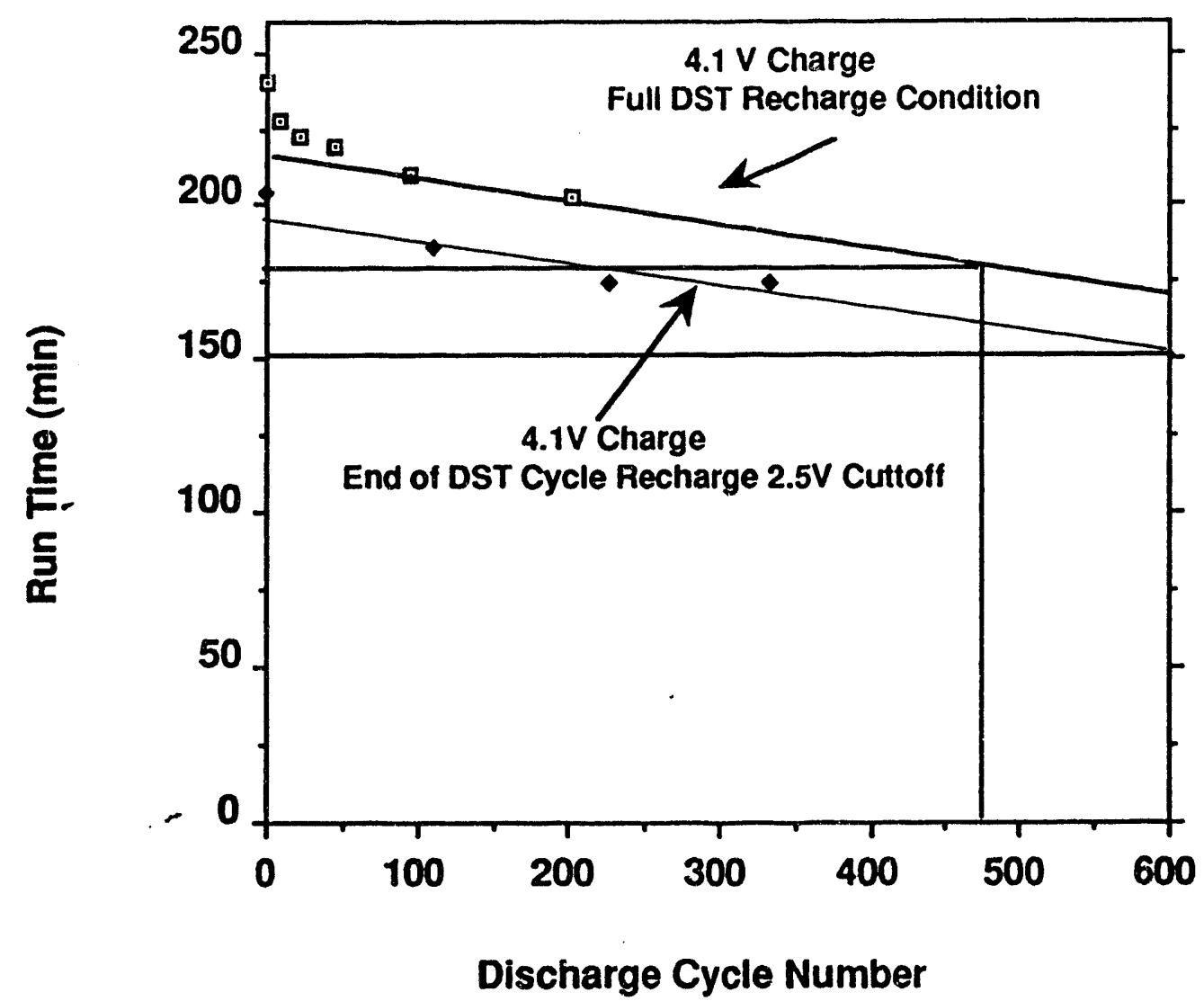

Figure 8- 4.1V Charge Cell Runtimes 


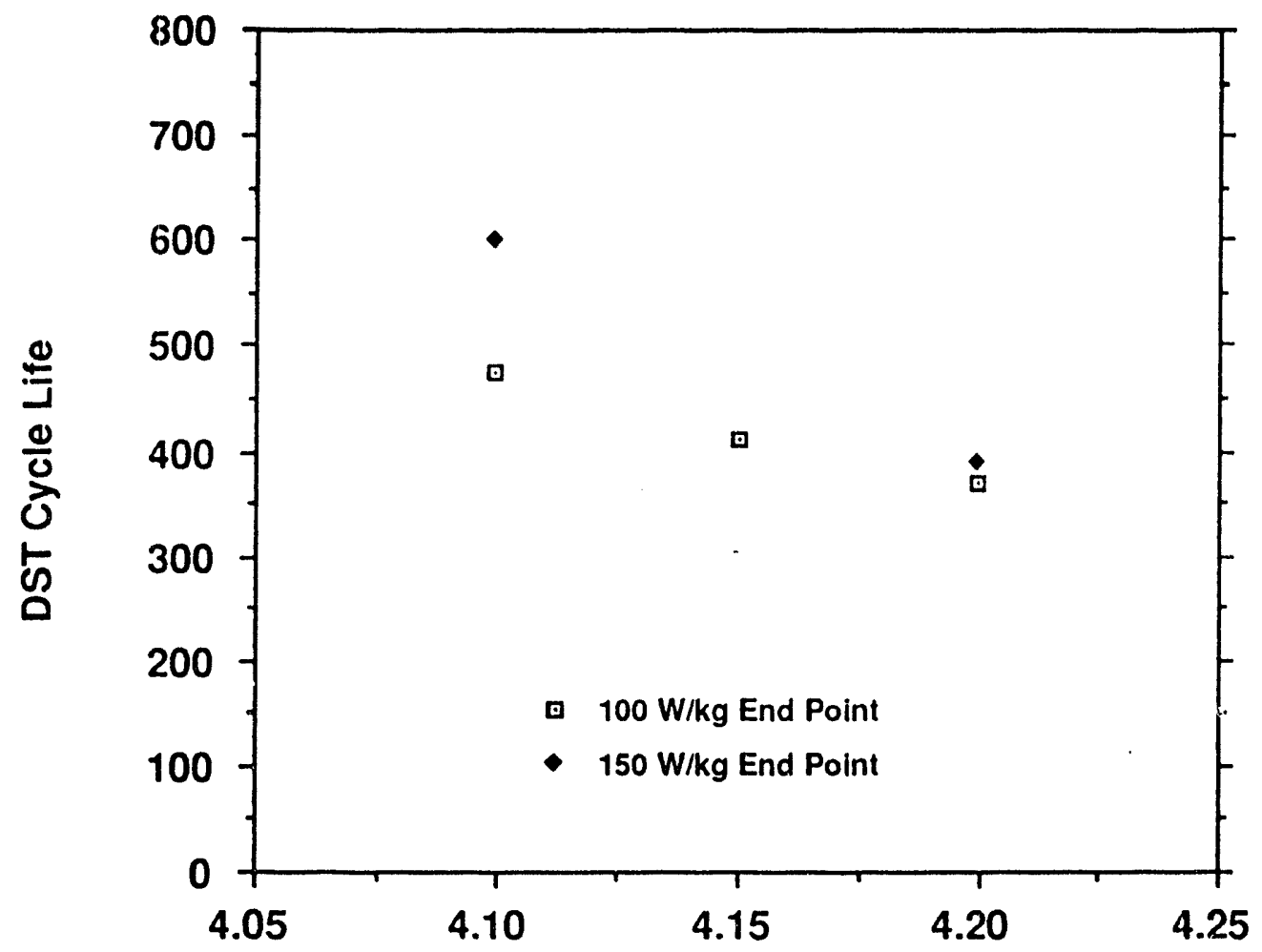

Charge Voltage

Figure 9-100\% DOD Cycle Life

The data of Table 2 and Figure 9, show that for the full DST end-point condition, the increase in runtime obtained by using a $4.2 \mathrm{~V}$ charge (the increase is about $7.5 \%$ ) results in a significant reduction in cycle life ( $79 \%$ of the $4.1 \mathrm{~V}$ charged cell). This result is more noticeable for cells which undergo immediate recharge at the $2.5 \mathrm{~V}$ cutoff (150 W/kg cutoff cells). Under these conditions, the runtime of the $4.2 \mathrm{~V}$ charged cell is $18 \%$ greater than the $4.1 \mathrm{~V}$ charged cell, but the cycle life is only $63 \%$ of the $4.1 \mathrm{~V}$ charged cell. The stress associated with both the higher charge voltage and higher DoD (i.e. full DST end-condition) both contribute significantly to cell degradation, but the relative effect of the high DoD end-point decreases at the higher charge voltage.

The changes in the end-of-discharge voltages with discharge cycle number for all of the partial discharge tests are shown in Figure 10. The voltage displayed is the voltage at the end of the peak-power discharge step in the DST cycle. It is again noted that the \%DoD is based on the $\mathrm{C} / 5$ rate energy of the cell at the a given charging voltage, and not capacity. A projected cycle life is arbitrarily estimated from the intercept of the extrapolated curves to $2.5 \mathrm{VC}$. Generally, the cycle life of the partial discharged

C This value, which is an indicator of when the cells can no longer supply the peak 150 W/kg discharge power pulse, is chosen because of the difficulty in estimating how much longer it would take to reach the full $100 \mathrm{~W} / \mathrm{kg}$ end point. 


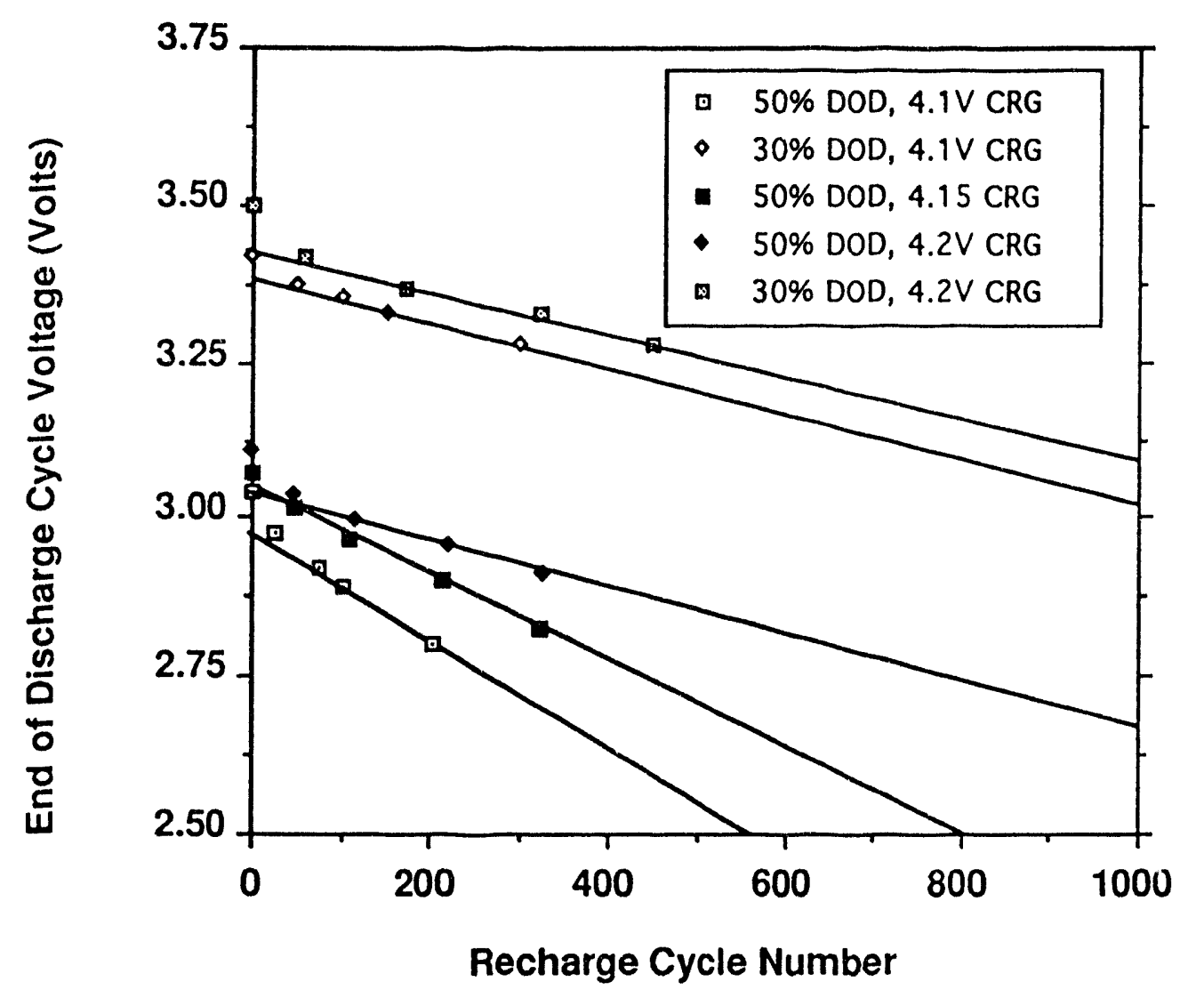

Figure 10- Low DoD Cycle Life

cells is greater than the $100 \%$ DoD tests, with the possible exception of the $50 \%$ DoD, 4.1V charged cell. These results show a reversing trend of cycle life with charging voltage, due to the relative contributions of charging and discharging stress. This behavior is probably associated with the fact that the $50 \%$ DoD cell charged at $4.2 \mathrm{~V}$ always has a lower average current and lower peak-power pulse current than the corresponding 4.1V charged cell. Though the difference in the end-of-discharge voltage of the two charging conditions is initially small, the difference increases substantially during cycling, apparently amplifying the effect. The projected cycle life of the $50 \%$ DoD, $4.2 \mathrm{~V}$ charged cell is more than twice that of the $4.1 \mathrm{~V}$ charged cell. The two $30 \%$ DoD results show degradation trend lines that are similar up to the termination point of the testing. Long cycle life can be obtained under these conditions.

The extrapolated estimates for the cycle lives of all cells is shown in Figure 11. In this figure, the \%DoD has been adjusted to reflect the \% DST runtimes relative to the full DST end condition at the same charge voltage. In this way, all the cells can be more equally compared. Also note that the \% DoD's, when considered this way, have been shifted to higher values. 


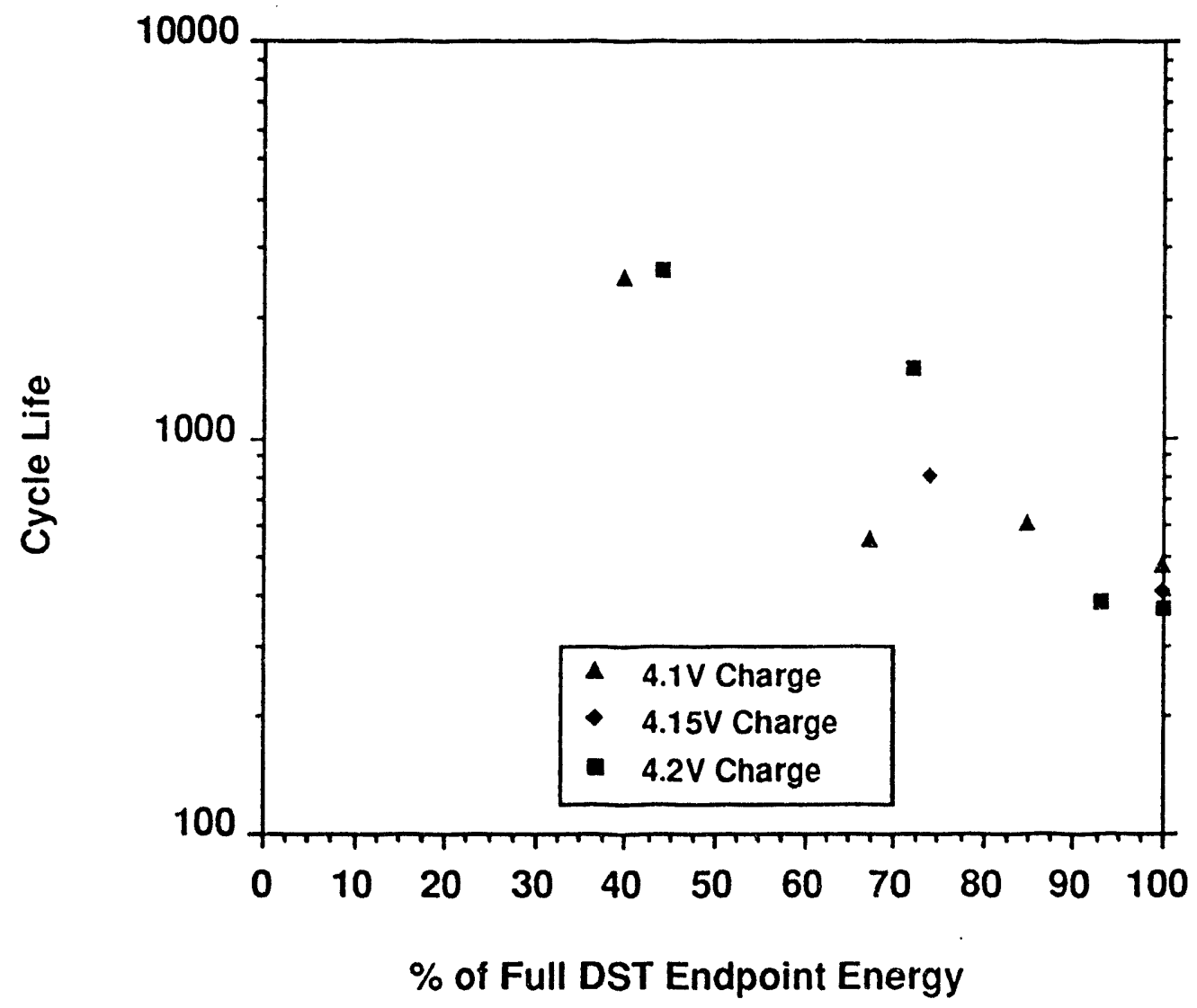

Figure 11- Cycle Life Under DST Conditions

(see text for details)

The results of Figure 11 are consistent with the data of Reference 1 for the cyclelife of a high-current discharged celll (a cell discharged at $0.9 \mathrm{~A}$ and $44 \% \mathrm{DoD}$, based on capacity, had a cycle life of 3600 cycles). It is estimated that the average power delivered during that discharge and over the cells life was $80 \mathrm{~W} / \mathrm{kg}$. It is important to note that, based on the trend line in Reference 1, a cell cycled at a similar DoD (44\%) but at a lower current $(0.36 \mathrm{~A}$, about $30 \mathrm{~W} / \mathrm{kg}$ average) would be expected to have a cycle life 5 time greater $(18,000$ cycles $)$.

Figure 12 shows estimates of the discharge energy that would be delivered over the life of the cells. This value is a better indicator of the driving life time or mileage range of the battery. At the highest DoD's $(>80 \%)$ charging voltage has a minor effect on total energy delivered, but at a lower DoD, the effect is more pronounced. Since the average power was $15 \mathrm{~W} / \mathrm{kg}$, DST driving times from 1300 to 4700 hours are predicted in the range of DoD's investigated.

At all DoD's, cell life is reduce due to the DST's high power stress requirement. Based on the result here and in Reference 1, cell life can be improved tremendously by reducing the battery DST peak-power requirement. The use of a load-leveling device (such as an double-layer capacitor) would help to make calendar life, rather than the 


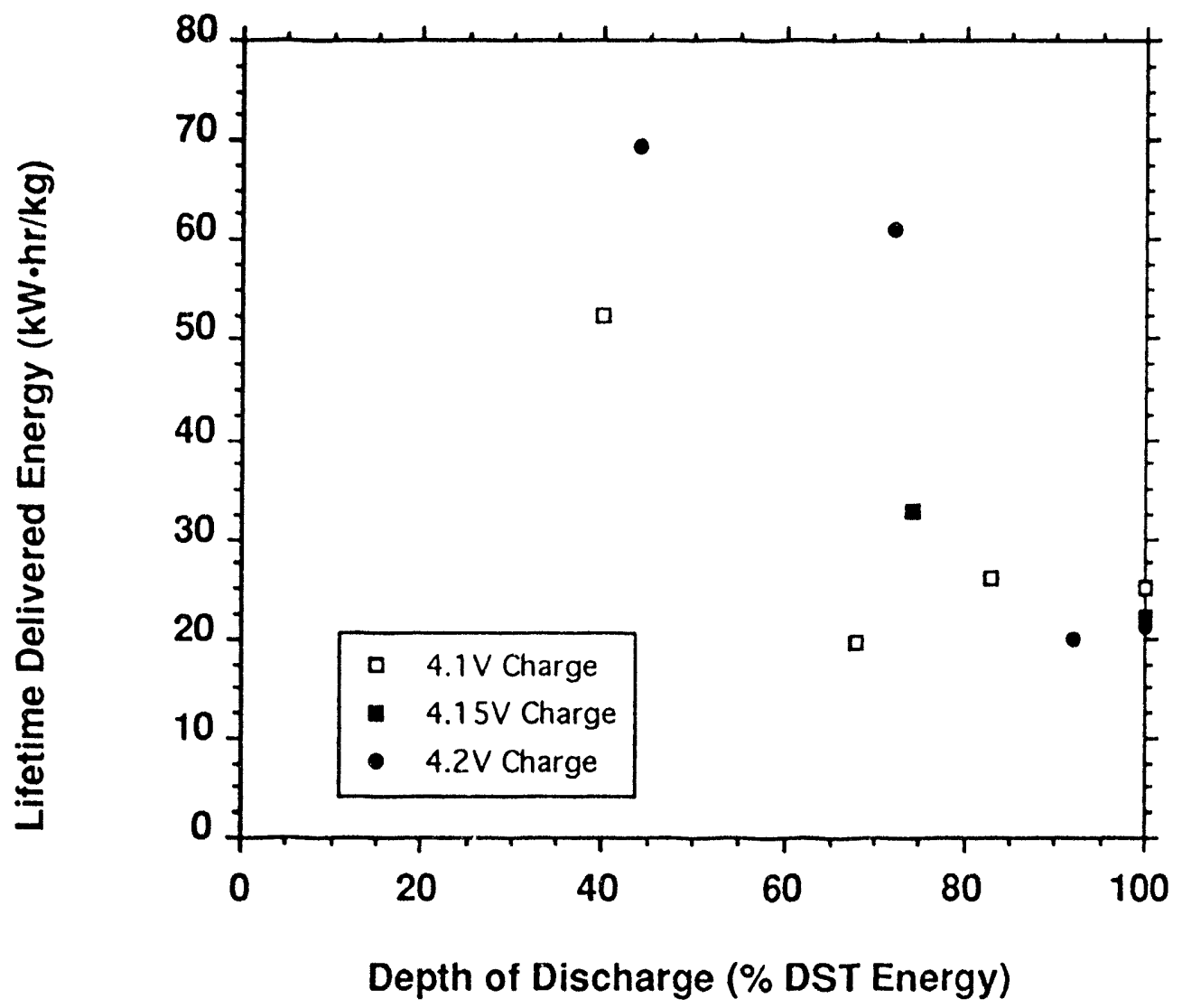

Figure 12

cycle-life, the limiting factor in cell design. Calculations based on data in Reference 1 indicate that load leveling might extend the lifetime delivered energy to $960 \mathrm{kWh} / \mathrm{kg}$ ( 64000 hours) at $30 \%$ DoD (about $24 \mathrm{Wh} / \mathrm{kg}$ delivered per cycle).

The $A C$ impedance of a full DST end-point, $V_{C}=4.2 \mathrm{~V}$ charge cell is shown in Figure 13 (Nyquist plot). The cell voltage in each case is 3.5V. (Note that the Nyquist semi-circles appear very oblong mostly because of the different scales of the $x$ and $y$ axis). The impedance spectrum shifts to more positive values during the cycling, reflecting an increase in the ohmic resistance. The radius of both the smaller high frequency loop, and the larger low frequency loops increases during cell cycling. This and other results confirm that initially, the Nyquist plots shift to more positive values, with small changes in the radius of the large loop. Later, both loops radius increase.

Figure 14 shows the relative increase in the $10 \mathrm{kHz}$ resistance (real component of cell impedance, relative to the cells initial resistance) for various charging voltage under the full DST discharge cycle. The rate of change of the high frequency resistance increases substantially with charging voltage. Figure 15 gives the same information for $\mathrm{V}_{\mathrm{C}}=4.2 \mathrm{~V}$ charged cell cycled under various DoD's. There is a 5-fold increase in the slope of the relative resistance versus cycle number curves from the $30 \%$ DoD to the full DST end-point condition. 


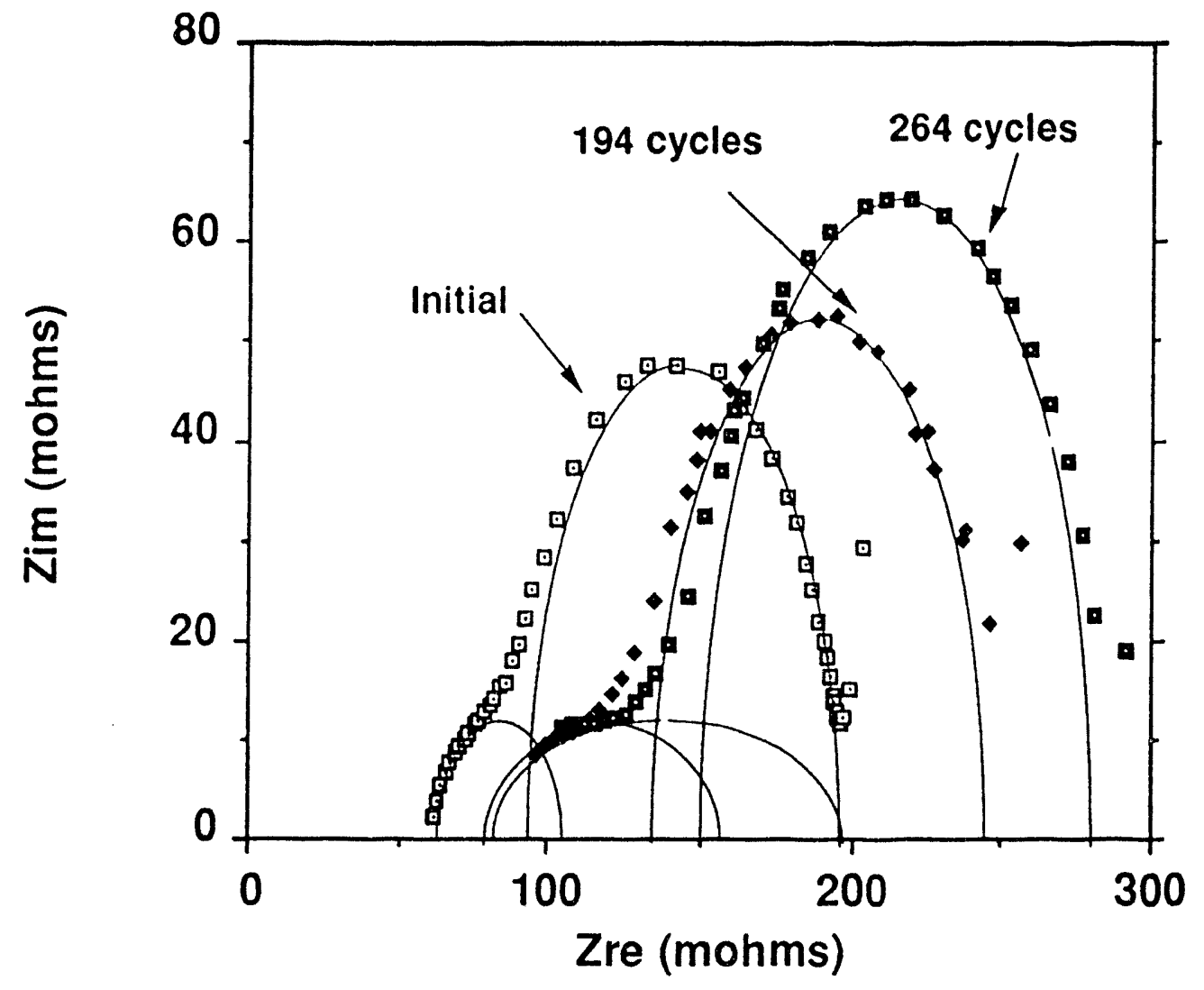

Figure 13- AC Impedance vs. Cycle Number 4.2V Charge Cell, Full DST Cycle

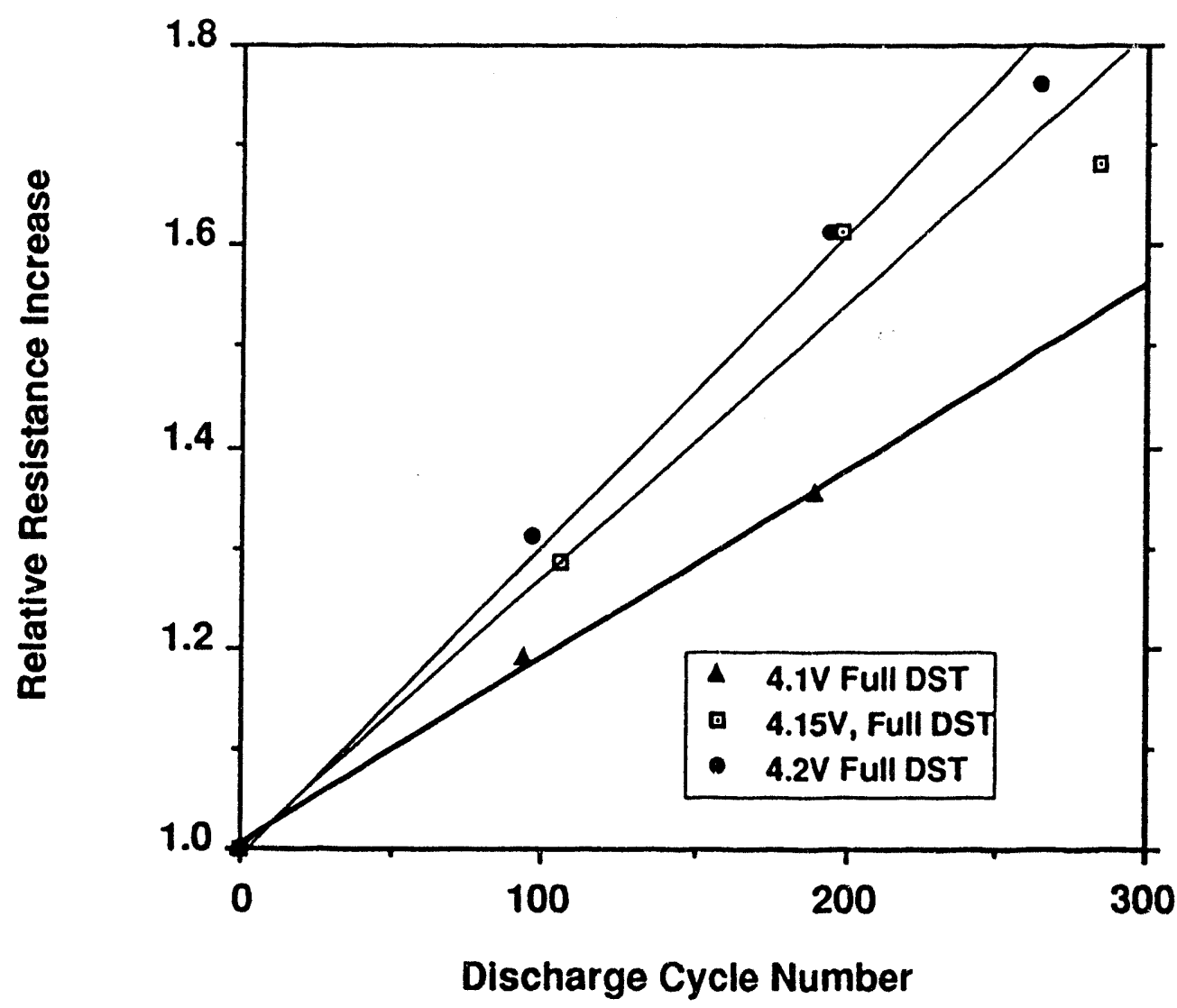

Figure 14- Changes in $10 \mathrm{kHz}$ Resistance 


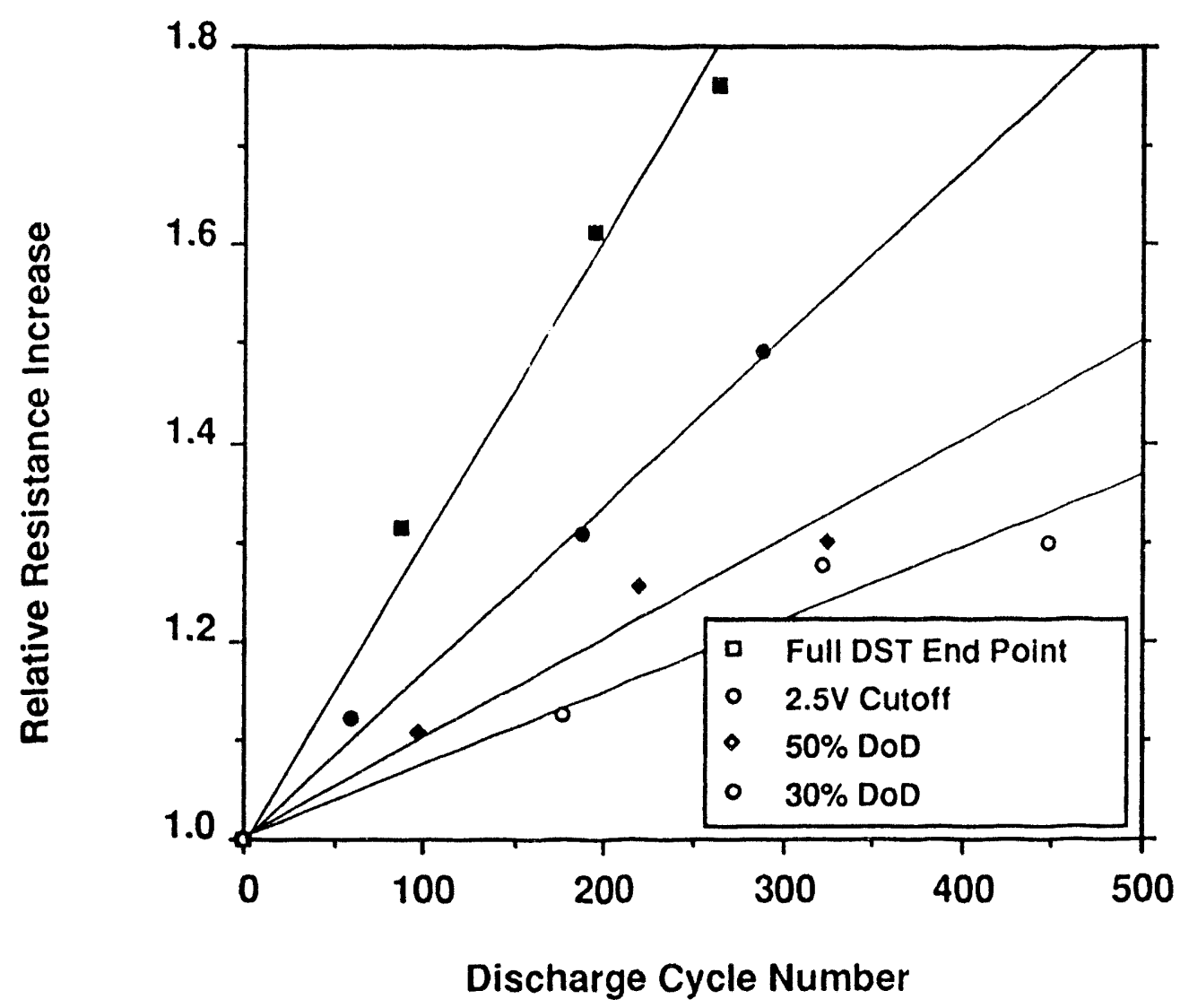

Figure $15-10 \mathrm{kHz}$ Resistance. $\mathrm{V}_{\mathrm{C}}=4.2 \mathrm{~V}$

Quantitatively, the changes in the high-frequency resistance does not correspond to the DST degradation pattern as a whole, and is not a good predictor of DST cycle life. This might be expected since the greatest changes in the impedance spectra during life and with state-of-charge occur at lower frequencies.

\section{Conclusions}

Dynamic Stress tests (DST) of small lithium-ion cells have demonstrated that the systems delivers high energy ( $65 \mathrm{Wh} / \mathrm{kg}$ maximum, $4.3 \mathrm{hrs}$ run time) with reasonable cycle-life (375-480 cycles) under the full USABC mid-term dynamic-stress-test conditions. At $44 \%$ DoD (with the \%DoD based on the maximum possible DST energy available) a substantially higher cycle life of 2800 cycles is projected. This value corresponds to DST driving for 1.9 hours every day for 7.7 years.

Both DoD and charging voltage $V_{c}$ affect the delivered energy and cell life in an interacting manner. At high DoD, a high $V_{c}$ increased the delivered energy by $8 \%$, but reduces the cycle life by $25 \%$. At intermediate DoD $(40-80 \%$ based on delivered energy) a higher $V_{C}$ is preferred, probably due to the reduced current and discharge 
stress applied to the cell. Finally, at very low DoD $(<40 \%)$, use of a higher $V_{C}$ (i.e. $>4.1 \mathrm{~V}$ ) may limit cycle life. Long-term tests are needed to verify this prediction.

The high power pulse of the DST test was shown to be both the energy (maximum run time) and life limiting-factor in these tests. If a high energy density load leveling technology is developed (e.g. flywheels or double layer capacitors) the delivered energy and cycle life could be substantially increase $(>10,000$ cycles, 95 Wh/kg).

\section{Acknowledgements}

This work was supported by the Assistant Secretary for Energy Efficiency and Renewable Energy, Office of Transportation Technologies, Electric \& Hybrid Propulsion Division of the U.S. Department of Energy and also under the auspices of the U.S. Department of Energy by the Lawrence Livermore National Laboratory under Contract No. W-7405-ENG-48.

\section{References}

1.) S. T. Mayer, J. H. Feikert, and J. L. Kaschmitter. "Cycle Life Testing of Lithium-lon Batteries for Small Satellite LEO Missions". AIAA Conference on Small Satellites, Utah State University, Logan, Utah. September 13-16, 1993. LLNL report UCRL-JC-114996.

2) United States Advanced Battery Consortium Press Release, Oct. 25, 1993. 

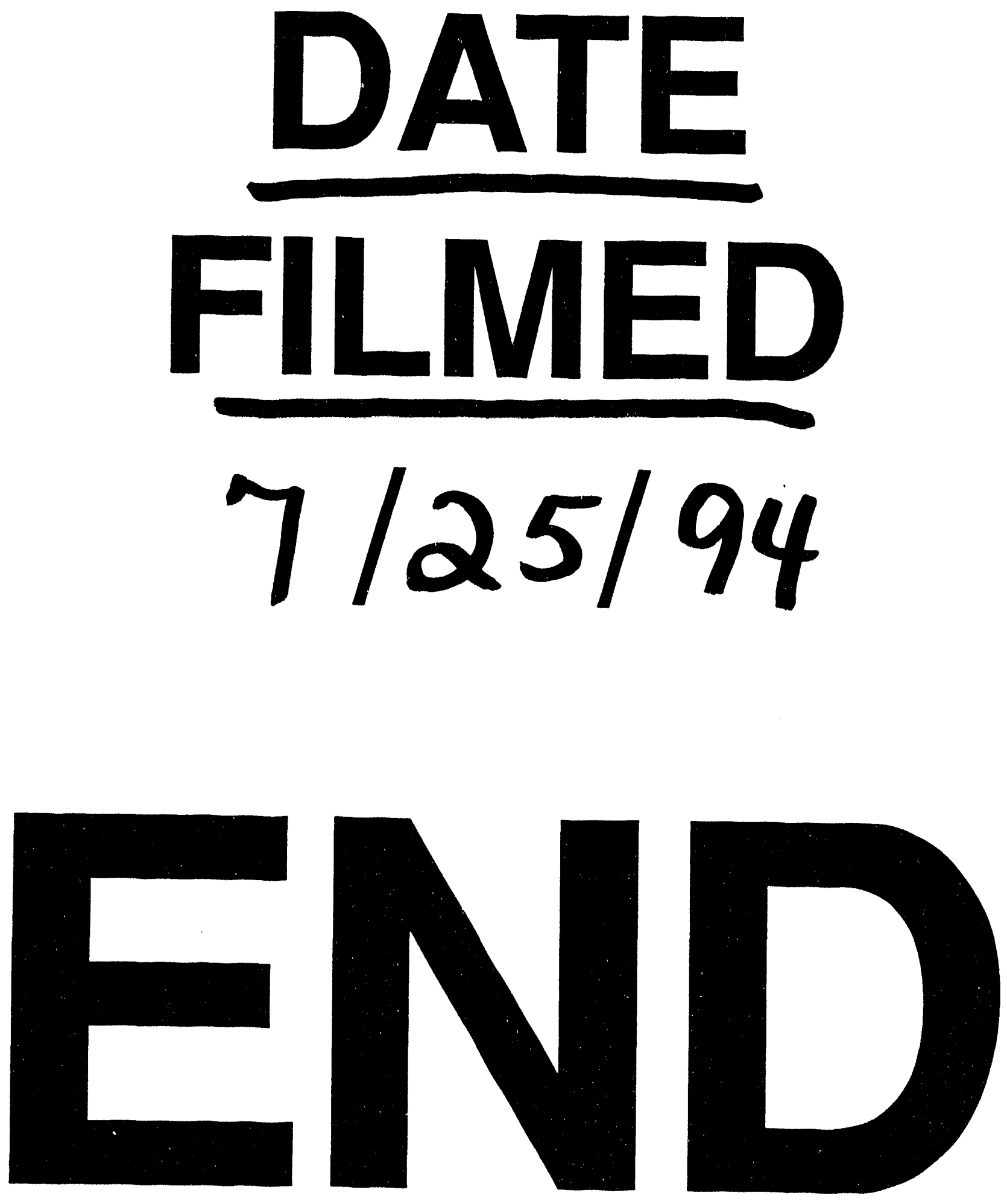
$\ldots$ 